\title{
Prevalence and Morphometric Analysis of Double Mental Foramen and Double Mandibular Foramen from Digital Panoramic Radiographs
}

\author{
Prevalencia y Análisis Morfométrico de Foramen Mental y Foramen \\ Mandibular Dobles a Través de Radiografías Panorámicas Digitales
}

Constanza Farfán ${ }^{1,2}$; Alain Arias ${ }^{1,3}$; Fernando José Dias ${ }^{1,3}$; Ivonne Garay ${ }^{3}$; Pablo Navarro ${ }^{1}$ \& Ramón Fuentes $^{1,3}$

FARFÁN, C.; ARIAS, A.; DIAS, F. J.; GARAY, I.; NAVARRO, P. \& FUENTES, R. Prevalence and morphometric analysis of double mental foramen and double mandibular foramen from digital panoramic radiographs. Int. J. Morphol., 38(3):714-719, 2020.

SUMMARY: The morphological variations of the mental foramen (MF) and mandibular foramen (MBF) have been studied for several years, and the prevalence and morphometric characteristics of double and triple foramina have been reported. The objective of this study was to establish the prevalence of variations in the MF and MBF, and to carry out a morphometric analysis of a Chilean population using digital panoramic radiographs. The study included 927 radiographs; the observed prevalence of double MF was $2.58 \%$, while the prevalence of double MBF was $1.51 \%$. No cases of triple foramina were found. In men, double MF was found more frequently in the left hemiarch (64.28\% of cases), while in women it was more frequent in the right hemiarch ( $80 \%)$. Double MBF was found more frequently in the right hemiarch in women ( $80 \%$ of cases), while the distribution between left and right in men was even. The mean area, width and height of the double MF were $5.46 \mathrm{~mm}^{2}, 2.77 \mathrm{~mm}$ and $2.57 \mathrm{~mm}$ respectively. The means of the same morphometric measurements in double MBF were $6.37 \mathrm{~mm}^{2}, 2.27 \mathrm{~mm}$ and $3.19 \mathrm{~mm}$ respectively. In both foramina, statistically significant differences were only found between the height of the foramen and the age of the subjects, with the observation that the greater the subject's age, the smaller the height. Dental surgeons must take these anatomical variants into consideration in clinical and surgical actions; timely diagnosis by radiograph is important to avoid possible complications.

KEY WORDS: Mental foramen; Mandibular foramen; Accessory foramen; Digital panoramic radiograph.

\section{INTRODUCTION}

The mental foramen (MF) is located in the anterolateral face of the body of the mandible, close to the inferior margin, generally between the first and second premolars (Olasoji et al., 2004; Al-Khateeb et al., 2007; El-Anwar et al., 2016; Fuentes et al., 2017). The visibility of the MF has been studied in panoramic radiographs in different populations. Ngeow et al. (2010) described a frequency of $77.8 \%$ in a Malay population. Chkoura \& El Wady (2013) analysed a Moroccan population sample and observed a frequency of $79 \%$. Fuentes et al. (2014) analysed the visibility of the MF in a Chilean population sample in conventional panoramic radiographs and reported a rate of $87.9 \%$, observing that detection of the MF is less frequent with advancing age and that it is more prevalent in men. The variations in this foramen have been studied in different populations in dry mandibles (Zografos \& Mutzuri, 1989; Roopa et al., 2003), radiographic imaging techniques like
CBCT (Naitoh et al., 2009a,b) and panoramic radiographs (Naitoh et al., 2011; Al-Shayyab et al., 2016; Srinivas et al., 2017); the reported prevalence varies between $3 \%$ and $7 \%$.

The mandibular foramen (MBF) is located in the centre of the mandibular ramus, and is related with the mandibular lingula (Monnazzi et al., 2012). Its position has been studied in dry mandibles, with the conclusion that the $\mathrm{MBF}$ is symmetrical on the two sides; however the literature on the anatomical reference points used to locate it is still scarce (Marzola et al., 2005). The MBF may be accompanied by an accessory foramen, which may or may not contain the vasculo-nervous bundle (Narayana \& Prashanthi, 2003; Das \& Suri, 2004; Manikandhan et al., 2010). The position of this accessory foramen has been studied more frequently in dry mandibles (Thangavelu et al., 2012; Matveeva et al., 2018).

\footnotetext{
${ }^{1}$ Research Centre for Dental Sciences (CICO), Dental School, Universidad de La Frontera, Temuco, Chile.

${ }^{2}$ Universidad Adventista de Chile, Chillán, Chile.

${ }^{3}$ Department of Integral Adults Dentistry, Dental School, Universidad de La Frontera, Temuco, Chile.
} 
Digital panoramic radiographs offer good possibilities of detecting accessory foramina, due to the continuity and extent of the image. This examination, used for diagnostic purposes in dental practice, provides an image of sufficiently good quality to allow immediate viewing of the patient's whole maxillofacial area (Fuentes et al., 2014), as well as being quick and safe for users (Pyun et al., 2013). Discovering variations in the shape, size and position of the foramina has become an essential step for dental surgeons prior to any surgery, due to their intimate relation with the inferior alveolar nerve (Balcioglu et al., 2010; Gupta et al., 2015). Correct identification of these morphological variations is useful for avoiding injury during anaesthetic and surgical procedures, such as the placing of implants, periapical surgery, endodontic treatment and orthognathic surgery (Cillo \& Stella, 2005; AlKhateeb et al.). The aim of this study was therefore to establish the prevalence of variations in the MF and MBF, and to carry out a morphometric analysis of a Chilean population using digital panoramic radiographs.

\section{MATERIAL AND METHOD}

A cross-sectional study was carried out, approved by the Scientific Ethics Committee (CEC) of Universidad de La Frontera (Folio no. 015/2014). The study analysed digital panoramic radiographs (ratio 1:1) taken using the standard technique with a PAX-400C orthopantomograph (VATECH, Korea, 2010), between January 2010 and December 2015, in the Dental Teaching Clinic of the Dental School, Universidad de La Frontera, Temuco, Chile. The measurements were made by two previously calibrated examiners and a third examiner, a dental surgeon specialising in radiology, who was responsible for taking a decision in doubtful cases.

A total of 1400 digital panoramic radiographs were available for analysis. The following exclusion criteria were applied: radiographs with inadequate image quality (distortion or alteration in the contrast), patients with teeth in intraosseous evolution (except third molars), presence of any pathology or development conditions which affected the visibility of the study area (tumours, cysts, fractures or malformations), isolated radio-opacities in edentate areas which may be associated with excessive ossification in a post operatory site, and radiographs showing evidence of orthognathic surgery.

Because it is impossible to tell which is the accessory foramen in cases of double or triple MF or MBF, all the foramina present were included in the analysis. To determine the morphometric measurements of double or triple foramina we used the ImageJ software (version 1.45), which allows the user to draw lines and to measure distances, areas and angles of the various anatomical references observed in the radiograph. In each selected image we determined the area, width (greatest horizontal measurement) and height of the foramen (greatest vertical measurement) as shown in Figure 1. For statistical analysis we used the SigmaPlot 12.0 software, analysing the variables sex and age range $(<30$ years, >30 years) and relating them with the area, height (supero-inferior) and width (medio-lateral) of each foramen (double MF and double MBF).
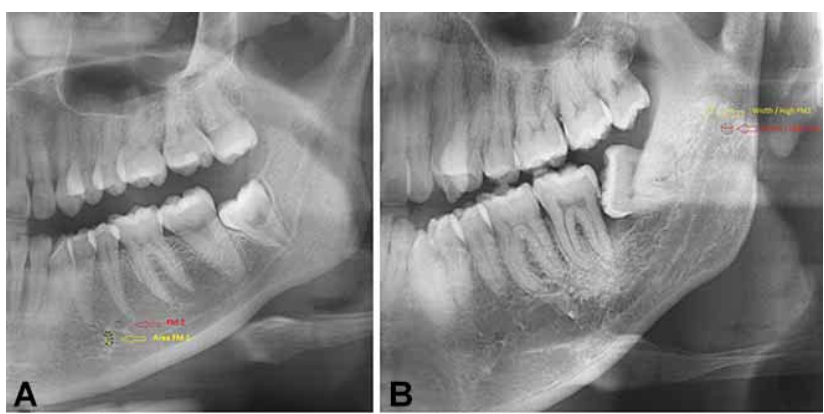

Fig. 1. Digital panoramic radiograph showing the measurements taken in ImageJ software (version 1.45). A) Measurement of the area of a double MBF, B) Measurement of the width (greatest horizontal measurement) $(*)$ and height (greatest vertical measurement) (à) of a double MF.

\section{RESULTS}

In total, 927 radiographs were included in the study, after applied selection criteria, of which 327 belonged to men (35.27 $\%)$ and 600 to women $(64.72 \%)$. The patients' ages ranged between 18 and 86 years (mean age $36 \pm 16.23$ ). Only double $\mathrm{MF}$ and MBF were observed, no triple foramina were found.

Double mental foramen. We observed 24 cases $(2.58 \%)$ of double MF (Fig. 2A) among all the radiographs analysed. $58.33 \%$ of cases $(n=14)$ were men aged between 18 and 53 years, while $41.67 \%$ of cases $(n=10)$ were women aged between 22 and 54 years. The position of the double MF was in the right hemiarch in $54.17 \%$ of cases $(n=13)$ and in the left hemiarch in $45.83 \%$ of cases $(n=11)$. In men there was a preponderance of cases in the left hemiarch, $64.28 \%$ of cases $(n=9)$, while in women the preponderance was in the right hemiarch, $80 \%$ of cases $(n=8)$. The mean area of the double MF identified was $6.25 \pm 3.96 \mathrm{~mm}^{2}(6.7 \pm 3.66$ $\mathrm{mm}^{2}$ for men and $5.85 \pm 4.48 \mathrm{~mm}^{2}$ for women). Table I shows the mean area, width and height of the double MF identified, grouped by sex and age range. There were 6 groups, but a statistically significant difference was found only between the height and the patient's age $(\mathrm{p}=0.015)$, with the observation that the greater the subject's age, the smaller the height. No cases of bilateral double MF were found. 

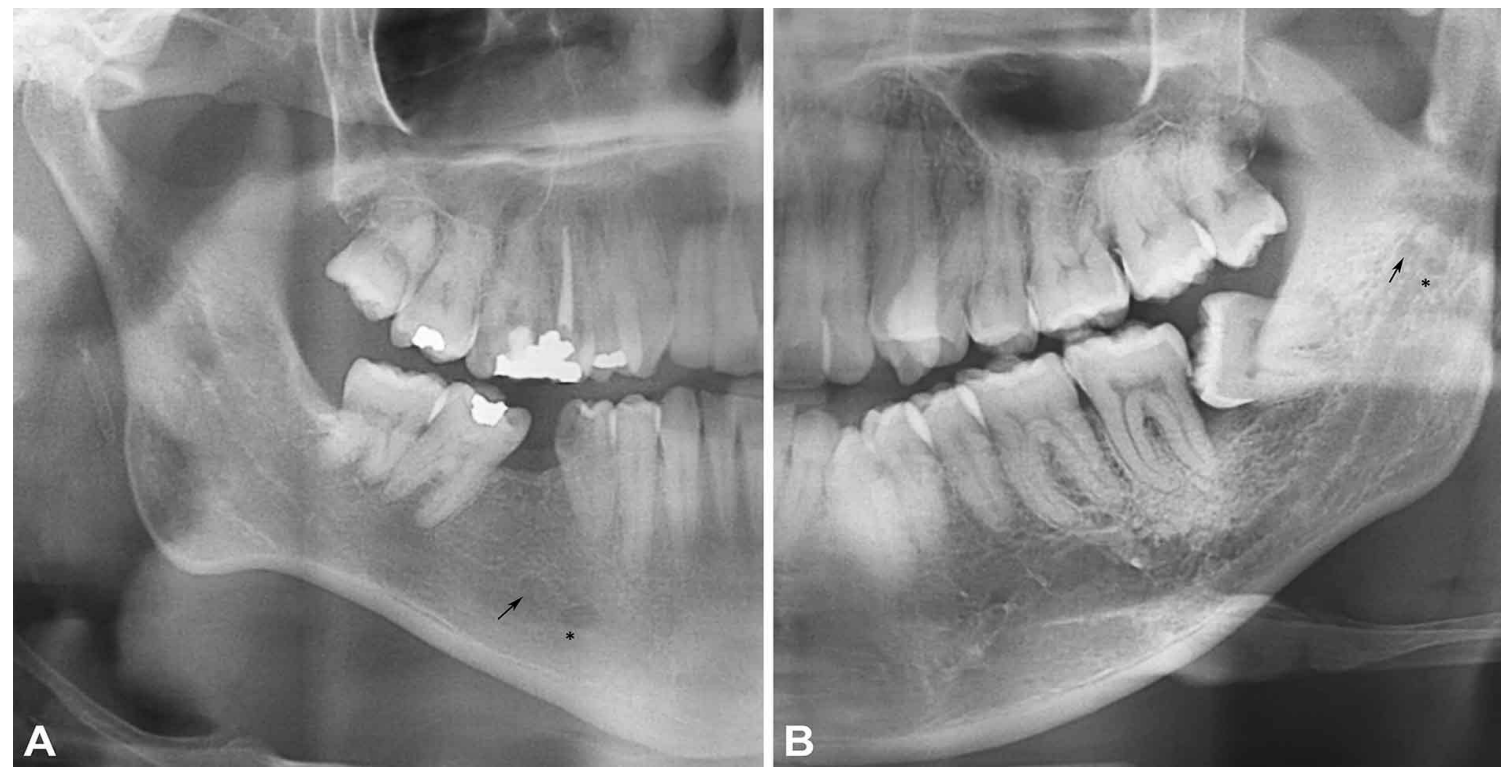

Fig. 2. Digital panoramic radiograph showing A) a double MF (à *), and B) a double MBF (à *).

Table I. Distribution of the data by median, Q1 and Q3, and p value of six groups distributed by the relationship of the area, width and height of the double MF with the patient's sex and age range.

\begin{tabular}{lccccc}
\hline Group & Variable & Median & $\mathbf{2 5}$ \% & $\mathbf{7 5}$ \% & p value \\
\hline \multirow{2}{*}{ AREA / SEX } & Area women & 4.139 & 3.047 & 7.093 & \\
& Area men & 6.259 & 3.722 & 9.125 & 0.124 \\
WIDTH / SEX & Width women & 2.284 & 2.207 & 3.623 & 0.058 \\
& Width men & 2.703 & 1.841 & 2.944 & 0.167 \\
HEIGHT / SEX & Height women & 2.310 & 1.616 & 2.863 & \\
& Height men & 2.51 & 1.917 & 3.238 & 0.264 \\
AREA/ AGE RANGE & $<30$ years & 5.651 & 3.840 & 6.677 & \\
\multirow{2}{*}{ WIDTH/ AGE RANGE } & $>30$ years & 3.492 & 2.738 & 9.092 & 0.464 \\
& $<30$ years & 2.628 & 2.017 & 3.440 & 0.015 \\
HEIGHT/ AGE & $>30$ years & 2.243 & 1.916 & 3.516 & 3.364 \\
RANGE & $<30$ years & 2.674 & 2.197 & 2.677 & \\
\hline
\end{tabular}

Table II. Distribution of the data by mean, standard deviation and $\mathrm{p}$ value of six groups distributed by the relationship of the area, width and height of the double MBF with the patient's sex and age range.

\begin{tabular}{cccccc}
\hline & Group & Variable & Mean & SD & p value \\
\hline & AREA / SEX & Area & 6.453 & 3.124 & \\
WIDTH / & Width women & 2.193 & 0.908 & & \\
SEX & Width men & 2.490 & 0.631 & 0.407 & \\
& HEIGHT / SEX & Height & 2.878 & 1.028 & 0.674 \\
& Height men & 3.325 & 1.048 & \\
& AREA/ AGE & $<30$ years & 2.864 & 0.906 & \\
RANGE & $>30$ years & 2.722 & 0.642 & 0.077 \\
& WIDTH/ AGE & $<30$ years & 2.677 & 0.874 & \\
RANGE & $>30$ years & 2.056 & 0.177 & 0.621 \\
& HEIGHT/ AGE & $<30$ years & 3.773 & 0.613 & 0.019 \\
& RANGE & $>30$ years & 2.878 & 1.028 & \\
\hline
\end{tabular}


Double mandibular foramen. We observed 14 cases (1.51 $\%$ ) of double MBF (Fig. 2B) among all the radiographs analysed. All cases were unilateral. $71.43 \%$ of cases $(n=10)$ were women aged between 18 and 55 years, while $28.57 \%$ of cases $(n=4)$ were men aged between 26 and 36 years. In women there was a preponderance of cases in the right hemiarch, $80 \%$ of cases $(n=8)$, while in men there was an even split between left and right hemiarch (50/50). The mean area of the double MBF identified was $6.55 \pm 2.89 \mathrm{~mm}^{2}$ $\left(6.79 \pm 2.38 \mathrm{~mm}^{2}\right.$ for men and $5.96 \pm 3.12 \mathrm{~mm}^{2}$ for women). Table II shows the mean area, width and height of the double MBF identified, grouped by sex and age range into 6 groups. As with the MF, a statistically significant difference was found only between the height and the patient's age ( $\mathrm{p}=0.019$ ), with the observation that the greater the subject's age, the smaller the height of the double MBF.

\section{DISCUSSION}

Various studies have reported the prevalence and characteristics of double MF and MBF, in different populations and using different instruments (Zografos \& Mutzuri; Al-Khateeb et al.; Manikandhan et al.; Naitoh et al., 2011; Afkhami et al., 2013). The frequency of double MF has been studied in dry mandibles and in CBCT, with reported frequencies of around $7 \%$ in Greek and Indian populations (Zografos \& Mutzuri; Roopa et al.), and $3 \%$ to $13 \%$ in Asiatic populations (Katakami et al., 2008; Naitoh et al., 2009a,b; Olivera-Santos et al., 2011; Imada et al., 2014; Srinivas et al.). In our study of digital panoramic radiographs in a sample of Chilean patients, we report a prevalence of $2.58 \%$; this is lower than that described in the literature (around $5 \%$ ) (Naitoh et al., 2011; Al-Shayyab et al.; Srinivas et al.). The percentage difference in the prevalence may be due to the sample size (much larger in our case) and to ethnic origin (most studies of prevalence have been carried out in Asian populations). The predominant hemiarch has been studied in an Indian population, where the left side is described as more frequent. This is the case in Singh \& Srivastava (2010), who found a prevalence of 5 $\%$ on the right side and $8 \%$ on the left (Kalender et al., 2012). Similarly, Udhaya et al. (2013) described a frequency of $2.22 \%$ on the right side and $3.33 \%$ on the left. These data contrast with our results, which show a preponderance in the right hemiarch $(1.4 \%)$ over the left $(1.18 \%)$. By sex, the preponderance of double MF was in the left hemiarch in men, and the right hemiarch in women; however Al-Shayyab et al. found a preponderance on the right side in both men and women. The literature on the size of double MF is scarce. Some studies report the diameter, from which the calculated mean area is $1.34 \mathrm{~mm}$ (Katakami et al.; Naitoh et al., 2009a,b; Oliveira-Santos et al., 2011; Imada et al.; El-Anwar et al.); others report the area, for example Naitoh et al. (2011) who reported a mean area of $1.5 \mathrm{~mm}^{2}$ in a study based on 365 panoramic radiographs. In our study the mean value was $5.46 \mathrm{~mm}^{2}$ for both sexes. Of all the variables analysed, only the relationship between the height of the foramen and the patient's age presented statistically significant results $(p=0.015)$, indicating that obliteration of the foramen in its supero-inferior dimension occurs with advancing age.

The MBF has been studied principally in dry mandibles. The reported prevalence of double MBF varies from $0.3 \%$ to $32.36 \%$ (Manikandhan et al.; Udhaya et al.; Shalini et al., 2016). Choi \& Han (2014) analysed 446 CBCT records and described a prevalence of $1.35 \%$, similar to our results obtained from panoramic radiographs $(1.51 \%)$; there are few reports in the literature using this method. In the same study, which analysed three types of accessory mandibular canals, type 3 was a canal originating in another foramen than the MBF; the prevalence of double MBF reported by the authors was $0.06 \%$ (Choi \& Han). In our study, the analysis by sex showed that there was a higher prevalence of double MBF in women (71.42\%), and that the predominant location was in the right hemiarch. This agrees with Freire et al. (2012) results in a population in Brazil, but contrasts with the results of Naitoh et al. (2009a,b) who describe predominance in the left side in an Asian population. As with the double MF, we analysed the height in relation to age and observed that a diminution in the supero-inferior dimension of the foramen occurs in patients aged over 30 years. This agrees with the findings of Al-Khateeb et al. who describe that the invisibility of the foramen increases with advancing age and is accentuated in patients aged over 50 years.

Studying the anatomical variables in the foramina is important, because lack of knowledge of these variations could explain failures in nerve block in this zone during surgery and routine dental procedures using conventional anaesthetic techniques.

\section{CONCLUSIONS}

Accessory MF and MBF occur infrequently in the Chilean population; in our results only double foramina were found, which were more frequent in the MF. In both foramina the supero-inferior height diminished in patients aged over 30 years. Consideration of these anatomical variants is important for dental surgeons carrying out various clinical and surgical actions, therefore radiograph diagnosis by either conventional or high resolution methods is necessary to avoid possible complications. 
FARFÁN, C.; ARIAS, A.; DIAS, F. J.; GARAY, I.; NAVARRO, P. \& FUENTES, R. Prevalencia y análisis morfométrico de foramen mental y foramen mandibular doble a través de radiografías panorámicas digitales. Int. J. Morphol., 38(3):714-719, 2020.

RESUMEN: Las variaciones morfológicas del foramen mental (FM) y mandibular (FMB) han sido estudiadas durante varios años, reportándose su prevalencia y las características morfométricas de forámenes dobles y triples. El objetivo de este estudio fue establecer la prevalencia de variaciones de los FM y FMB y realizar un análisis morfométrico a través de radiografías panorámicas digitales de una muestra de población chilena. En el estudio se incluyeron 927 radiografías y se observó una prevalencia de FM doble de 2,58 \%, mientras que la prevalencia de FMB doble fue de $1,51 \%$. No se encontraron casos de forámenes triples. En hombres, el FM doble se encontró mayoritariamente en la hemiarcada izquierda $(64,28 \%$ de los casos), mientras que en mujeres fue en la hemiarcada derecha ( $80 \%$ de los casos). Para el caso de los FMB dobles, en mujeres se presentó mayoritariamente en la hemiarcada derecha ( $80 \%$ de los casos), mientras que en hombres fue equitativo en ambos lados. El promedio del área, ancho y alto de los FM dobles fue de $5,46 \mathrm{~mm}^{2}, 2,77 \mathrm{~mm}$ y $2,57 \mathrm{~mm}$, respectivamente. Asimismo, los promedios de estas medidas morfométricas para el FMB doble fueron $6,37 \mathrm{~mm}^{2}, 2,27 \mathrm{~mm}$ y $3,19 \mathrm{~mm}$, respectivamente. Para ambos forámenes sólo se encontraron diferencias estadísticamente significativas entre el alto y la edad de los sujetos, observando que, a mayor edad menor era el alto del foramen. Los cirujanos dentistas deben tener en consideración estas variantes anatómicas para la realización de distintas acciones clínicas y quirúrgicas, su diagnóstico radiográfico oportuno es importante para prevenir posibles complicaciones.

PALABRAS CLAVES: Foramen mental ; Mandibular foramen; Foramen accesorio; Radiografía panorámica digital.

\section{REFERENCES}

Afkhami, F.; Haraji, A. \& Boostani, H. R. Radiographic localization of the mental foramen and mandibular canal. J. Dent. (Tehran), 10(5):436$42,2013$.

Al-Khateeb, T.; Al-Hadi Hamasha, A. \& Ababneh, K. T. Position of the mental foramen in a northern regional Jordanian population. Surg. Radiol. Anat., 29(3):231-7, 2007.

Al-Shayyab, M. H.; Alsoleihat, F.; Dar-Odeh, N. S.; Ryalat, S. \& Baqain, Z. H. The mental foramen II: Radiographic study of the superior-inferior position, appearance and accessory foramina in iraqi population. Int. J. Morphol., 34(1):310-9, 2016.

Balcioglu, H. A.; Kilic, C.; Varol, A.; Ozan, H.; Kocabiyik, N. \& Yildirim, M. A morphometric study of the maxillary artery and lingula in relation to mandibular ramus osteotomies and TMJ surgery. Eur. J. Dent., 4(2):166-70, 2010.

Chkoura, A. \& El Wady, W. Position of the mental foramen in a Moroccan population: A radiographic study. Imaging Sci. Dent., 43(2):71-5, 2013.

Choi, Y. Y. \& Han, S. S. Double mandibular foramen leading to the accessory canal on the mandibular ramus. Surg. Radiol. Anat., 36(9):851-5, 2014.

Cillo, J. E. \& Stella, J. P. Selection of sagittal split ramus osteotomy technique based on skeletal anatomy and planned distal segment movement: current therapy. J. Oral. Maxillofac. Surg., 63(1):109-14, 2005.
Das, S. \& Suri, R. K. An anatomico-radiological study of an accessory mandibular foramen on the medial mandibular surface. Folia Morphol. (Warsz), 63(4):511-3, 2004.

El-Anwar, M. W.; Sweed, A. H. \& Abdulmonaem, G. Mental foramen relation to mandibular fracture. J. Craniofac. Surg., 27(8):e743-e745, 2016.

Freire, A. R., Rossi, A. C., Prado, F. B.; Caria, P. H. F. \& Botacin, P. R. Incidence of the mandibular accessory foramina in Brazilian population. Braz. J. Morphol. Sci., 29(3):171-3, 2012.

Fuentes, R.; Cantin, M.; Navarro, P.; Borie, E.; Beltrán, V. \& Bucchi, C. Characterization of anatomical structures using panoramic radiographs: the mental foramen. Int. J. Morphol., 32(4):1423-9, 2014.

Fuentes, R.; Flores, T.; Dias, F. J.; Farfán, C.; Astete, N.; Navarro. P. \& Arias, A. Localization of the mental foramen through digital panoramic radiographs in a Chilean population. Int. J. Morphol., 35(4):1309-15, 2017.

Gupta, V.; Pitti, P. \& Sholapurkar, A. Panoramic radiographic study of mental foramen in selected dravidians of south Indian population: A hospital based study. J. Clin. Exp. Dent., 7(4):e451-6, 2015.

Imada, T. S.; Fernandes, L. M.; Centurion, B. S.; de Oliveira-Santos, C.; Honório, H. M. \& Rubira-Bullen, I. R. Accessory mental foramina: prevalence, position and diameter assessed by cone-beam computed tomography and digital panoramic radiographs. Clin. Oral Implants Res., 25(2):e94-9, 2014.

Kalender, A.; Orhan, K. \& Aksoy, U. Evaluation of the mental foramen and accessory mental foramen in Turkish patients using cone-beam computed tomography images reconstructed from a volumetric rendering program. Clin. Anat., 25(5):584-92, 2012.

Katakami, K.; Mishima, A.; Shiozaki, K.; Shimoda, S.; Hamada, Y. \& Kobayashi, K. Characteristics of accessory mental foramina observed on limited cone-beam computed tomography images. J. Endod., 34(12):1441-5, 2008.

Manikandhan, R.; Mathew, P. C.; Naveenkumar, J. \& Anantanarayanan, P. A rare variation in the course of the inferior alveolar nerve. Int. J. Oral Maxillofac. Surg., 39(2):185-7, 2010.

Marzola, C.; Frare, P. H. B.; Toledo Filho, J. L. \& Navarro, J. A. C. Forame da mandíbula: contribuição sobre sua localização para as técnicas anestésicas. Rev. Electron. Odontol. Acad. Tiradentes Odontol. (Bauru), 5(2):235-58, 2005.

Matveeva, N.; Popovska, L.; Evrosimovska, B.; Chadikovska, E. \& Nikolovska, J. Morphological alterations in the position of the mandibular foramen in dentate and edentate mandibles. Anat. Sci. Int., 93(3):340-50, 2018.

Monnazzi, M. S.; Passeri, L. A.; Gabrielli, M. F.; Bolini, P. D.; de Carvalho, W. R. \& da Costa Machado, H. Anatomic study of the mandibular foramen, lingula and antilingula in dry mandibles, and its statistical relationship between the true lingula and the antilingula. Int. J. Oral Maxillofac. Surg., 41(1):74-8, 2012.

Naitoh, M.; Hiraiwa, Y.; Aimiya, H.; Gotoh, K. \& Ariji, E. Accessory mental foramen assessment using cone-beam computed tomography. Oral Surg. Oral Med. Oral Pathol. Oral Radiol. Endod., 107(2):289-94, $2009 \mathrm{~b}$.

Naitoh, M.; Nakahara, K.; Hiraiwa, Y.; Aimiya, H.; Gotoh, K. \& Ariji, E. Observation of buccal foramen in mandibular body using cone-beam computed tomography. Okajimas Folia Anat. Jpn., 86(1):25-9, 2009a.

Naitoh, M.; Yoshida, K.; Nakahara, K.; Gotoh, K. \& Ariji, E. Demonstration of the accessory mental foramen using rotational panoramic radiography compared with cone-beam computed tomography. Clin. Oral Implants Res., 22(12):1415-9, 2011.

Narayana, K. \& Prashanthi, N. Incidence of large accessory mandibular foramen in human mandibles. Eur. J. Anat., 7(3):139-41, 2003.

Ngeow, W. C.; Dionysius, D. D.; Ishak, H. \& Nambiar, P. Effect of ageing towards location and visibility of mental foramen on panoramic radiographs. Singapore Dent. J., 31(1):15-9, 2010.

Olasoji, H. O.; Tahir, A.; Ekanem, A. U. \& Abubakar, A. A. Radiographic and anatomic locations of mental foramen in northern Nigerian adults. Niger. Postgrad. Med. J., 11(3):230-3, 2004. 
Oliveira-Santos, C.; Souza, P. H.; De Azambuja Berti-Couto, S.; Stinkens, L.; Moyaert, K.; Van Assche, N. \& Jacobs, R. Characterisation of additional mental foramina through cone beam computed tomography. J. Oral Rehabil., 38(8):595-600, 2011.

Pyun, J. H.; Lim, Y. J.; Kim, M. J.; Ahn, S. J. \& Kim, J. Position of the mental foramen on panoramic radiographs and its relation to the horizontal course of the mandibular canal: a computed tomographic analysis. Clin. Oral Implants Res., 24(8):890-5, 2013.

Roopa, R.; Manjunath, K. Y. \& Balasubramanum, V. The direction and location of mental foramen and incidence of accessory mental foramen in south Indian mandibles. Indian J. Dent. Res., 14(1):57-8, 2003.

Shalini, R.; RaviVarman, C.; Manoranjitham, R. \& Veeramuthu, M. Morphometric study on mandibular foramen and incidence of accessory mandibular foramen in mandibles of south Indian population and its clinical implications in inferior alveolar nerve block. Anat. Cell Biol., 49(4):241-8, 2016

Singh, R. \& Srivastava, A. K. Study of position, shape, size and incidence of mental foramen and accessory mental foramen in indian adult human skulls. Int. J. Morphol., 28(4):1141-6, 2010.

Srinivas, N.; Ramdurg, P.; Puranik, S. R.; Sali, K. \& Ingaleshwar, P. The position of the mental foramen in the north and south Indian populations. Acta Med. Acad., 46(1):44-9, 2017.

Thangavelu, K.; Kannan, R.; Senthil Kumar, N.; Rethish, E.; Sabitha, S. \& SayeeGanesh, N. Significance of localization of mandibular foramen in an inferior alveolar nerve block. J. Nat. Sci. Biol. Med., 3(2):156-60, 2012.

Udhaya, K.; Saraladevi, K. V. \& Sridhar, J. The morphometric analysis of the mental foramen in adult dry human mandibles: a study on the South Indian population. J. Clin. Diagn. Res., 7(8):1547-51, 2013.

Zografos, J. \& Mutzuri, A. Incidence of double mental foramen in a sample of Greek population. Odontostomatol. Proodos., 43(6):521-3, 1989.
Corresponding author:

Prof. Dr. Ramón Fuentes Fernández

Research Centre for Dental Sciences (CICO)

Dental School

Universidad de La Frontera

Av. Francisco Salazar 1145

Temuco

CHILE

Email: ramon.fuentes@ufrontera.cl

Received: 02-09-2019

Accepted: 29-10-2019 